\title{
Carbon and nitrogen winter storage and remobilisation during seasonal flush growth in two-year-old cork oak (Quercus suber L.) saplings
}

\author{
Sofia Cerasoli ${ }^{\mathrm{a}, \mathrm{b} *}$, Pascale MAILlard ${ }^{\mathrm{c}}$, Andrea SCARTAZZA $^{\mathrm{d}}$, Enrico BrUGNOLI $^{\mathrm{d}}$, \\ Maria Manuela CHAVES ${ }^{\mathrm{a}, \mathrm{b}}$, João Santos PEREIRA ${ }^{\mathrm{a}}$ \\ a Instituto Superior de Agronomia, Tapada da Ajuda, 1349-017 Lisbon, Portugal \\ b Instituto de Tecnologia Química e Biológica, Aptd. 12, 2781-901 Oeiras, Portugal \\ c UMR INRA-Université Henri Poincaré, Écologie et Écophysiologie Forestières, INRA Centre de Nancy, 54280 Champenoux, France \\ d Consiglio Nazionale delle Ricerche, Istituto de Biologia Agroambientale e Forestale, Via Guglielmo Marconi 2, \\ Villa Paolina, 05010 Porano (TR), Italy
}

(Received 1 April 2003; accepted 20 August 2003)

\begin{abstract}
A dual long-term ${ }^{13} \mathrm{C}$ and ${ }^{15} \mathrm{~N}$ labeling was used to assess the contribution of winter assimilated carbon $(\mathrm{C})$ and nitrogen $(\mathrm{N})$ for the spring growth flush of two-year-old cork oak plants. Changes in concentrations and partitioning of winter assimilated $\mathrm{C}$ and $\mathrm{N}$, total $\mathrm{C}$ and $\mathrm{N}$, and total-non-structural carbohydrates were followed from January to August in the various plant parts (first year and second year leaves, stem, branches, coarse and fine roots). No loss of winter $\mathrm{C}$ and $\mathrm{N}$ was observed with time suggesting that winter assimilates are retained within the plant and contribute to storage. A strong mobilisation of $\mathrm{C}$ and $\mathrm{N}$ was demonstrated from first year leaves and fine roots during the spring growth flush. Leaves from the second year and, to lesser extent, branches acted as sinks for winter $\mathrm{C}$ and $\mathrm{N}$. At the beginning of the new leaf growth, a significant decrease in starch concentration occurred in first year leaves. In August, before leaf fall we observed also a mobilisation from first year to second year leaves, of $\mathrm{N}$ assimilated after labeling. We conclude that under these experimental conditions, both winter and current $\mathrm{C}$ and $\mathrm{N}$ were used for the spring growth flush of the cork oak plants. The foliage grown during the previous year was a source of winter and recently assimilated $\mathrm{N}$ and a source of $\mathrm{C}$ from recent assimilates for the new growth in the spring.
\end{abstract}

Quercus suber / 13C labeling / 15N labeling / remobilisation / carbohydrates

Résumé - Mise en réserve hivernale du carbone et de l'azote et remobilisation lors de la croissance saisonnière de chênes-lièges (Quercus suber L.) âgés de deux ans. Un double marquage ${ }^{13} \mathrm{C}$ et ${ }^{15} \mathrm{~N}$ à long terme a été réalisé afin d'évaluer la contribution du carbone (C) et de l'azote $(\mathrm{N})$ assimilés durant l'hiver, à la croissance printanière de chênes-lièges âgés de deux ans. Les évolutions concomitantes des concentrations et de la répartition du $\mathrm{C}$, du $\mathrm{N}$, ainsi que la concentration en glucides totaux non structuraux, ont été suivies de janvier à août dans les différents organes (feuilles préexistantes et printanières, tige principale, rameaux axillaires, grosses et fine racines) des jeunes arbres Le $\mathrm{C}$ et le $\mathrm{N}$ assimilés durant l'hiver ne sont pas perdus par les plants. Une forte mobilisation de $\mathrm{C}$ et de $\mathrm{N}$ est observée au printemps, pendant la période de croissance aérienne, au niveau des feuilles préexistantes et des racines fines. Les feuilles développées au printemps et, dans une moindre mesure les rameaux axillaires, importent le $\mathrm{C}$ et le $\mathrm{N}$ assimilés durant l'hiver. Lorsque la croissance des nouvelles feuilles démarre, une diminution significative de la concentration en amidon est observée dans les feuilles préexistantes. En août, lors de leur sénescence, une exportation d'azote nouvellement assimilé est aussi observée au niveau des feuilles préexistantes. Nous concluons que, dans nos conditions expérimentales, il existe une coopération entre le $\mathrm{C}$ et le $\mathrm{N}$ assimilés en hiver et au printemps pour assurer la croissance printanière des plants de chêne-liège. Il est démontré en outre que feuilles préexistantes sont une source de $\mathrm{N}$ hivernal et de $\mathrm{C}$ et de $\mathrm{N}$ nouvellement assimilés pour cette nouvelle croissance.

Quercus suber / marquage ${ }^{13} \mathrm{C} /$ marquage ${ }^{15} \mathrm{~N} /$ remobilisation / carbohydrates

\section{INTRODUCTION}

It has been widely demonstrated that in deciduous trees wood and roots are major reservoirs for carbon $(\mathrm{C})$ and nitrogen (N) storage [4, 12]. Consequently, these organs will have an important role during winter and early spring in supplying $\mathrm{C}$ and $\mathrm{N}$ for maintenance metabolism and new growth. In evergreens, pre-existing leaves can also behave as sources of $\mathrm{C}$ and $\mathrm{N}$ as new growth occurs. Starch is often considered as the main form of $\mathrm{C}$ storage in plants. The mobilization and utilization of

\footnotetext{
* Corresponding author: sofiac@ @isa.utl.pt
} 
stored $\mathrm{C}$ implies the hydrolysis of starch and the synthesis of sucrose, which is the main form of transport in plants [15]. Consequently, mobilisation of starch results in a depletion of its concentration in organs where it accumulated. In stem of deciduous species like hybrid poplar [33] and silver birch (Betula pendula Roth) [25], as in wood and roots of young walnut trees (Juglans regia L.) [11] the lowest starch concentrations were observed just before bud break. In evergreens, a similar decrease was observed in wood [5] in roots [10], and also in one and two-year old needles [5]. In evergreens species starch depletion was to a lesser extent than in deciduous consequence of storage mobilisation, whereas the major fraction of starch depletion was due to the decrease in the flow of photosynthates directed downwards when the sink strength of sprouts increased.

Also patterns of $\mathrm{N}$ storage and remobilisation show particularities inherent to deciduous and evergreen species. In deciduous trees such as peach (Prunus persica (L.) Batsch), $\mathrm{N}$ is massively withdrawn before leaf senescence from leaves to shoots and roots where it is stored until the next growing season, when it is used to support new leaf growth [30]. In evergreens, $\mathrm{N}$ is translocated from previous years' leaves, not only before their fall [19] but in contrast to deciduous trees, also during the whole leaf lifetime [32]. Similarly to deciduous species, N remobilisation in evergreens was demonstrated not only from leaves but also from roots and wood, as shown in Sitka spruce (Picea sitchensis (Bong.) Carr.) [18] and orange trees (Citrus sinensis (L.) Osbeck) [13].

Cork oak (Quercus suber L.) is a broadleaved evergreen from Mediterranean region with a leaf life span of about one year, a short longevity compared to leaf lifetime of other evergreens such as conifers [6]. In adult trees, previous year's leaves usually fall along with the spring growth flush of new leaves at the beginning of summer [8]. A second growth flush, less intense, can also occur in autumn if environmental conditions allow it [23]. Little is known about $\mathrm{C}$ and $\mathrm{N}$ balances in cork oak, either in young or adult trees grown under natural conditions. Some studies examined seasonal dynamics of $\mathrm{N}$ concentration in leaves [20] and in litterfall [27]. However, at our knowledge, only one study investigated mechanisms of $\mathrm{N}$ storage and remobilisation in cork oak during winter and following spring [1] and none considered together dynamics of $\mathrm{C}$ and $\mathrm{N}$ during these periods. Nevertheless, as seen above, these processes are important prerequisites for evergreens to ensure new growth in spring and to resist to biotic and abiotic stresses [2]. Moreover, as a consequence of global climate change, more arid conditions are predicted to occur in the Mediterranean region [21]. A basic knowledge on the utilisation of reserves could be of great help for future investigations endeavouring to understand the ability of this species to survive to future challenges.

Previous studies demonstrated that dual labeling of plants with stable isotopes of $\mathrm{C}$ and $\mathrm{N}$ is a powerful tool to follow their partitioning within the plant [16] and to distinguish recycling from new uptake [22]. In the present study, cork-oak saplings were subjected to a dual long-term labeling with ${ }^{13} \mathrm{C}$ and ${ }^{15} \mathrm{~N}$ isotopes in winter, when no growth was expected. In this way, $\mathrm{C}$ and $\mathrm{N}$ stored in winter were labeled, allowing to evaluate, the next spring, the relative contribution for the growth of new organs, of $\mathrm{C}$ and $\mathrm{N}$ remobilised from storage tissues or recently acquired by new $\mathrm{N}$ uptake and $\mathrm{C}$ assimilation.

With this approach we attempted to answer to the following questions: (1) What is the contribution of winter stored $\mathrm{C}$ and $\mathrm{N}$ for next spring and summer flush growth; (2) Which organs in cork oak act as sources of stored $\mathrm{C}$ and $\mathrm{N}$ and which are their respective sinks; (3) Whether sinks' strength can induce modifications in the $\mathrm{C} / \mathrm{N}$ equilibrium under non-limiting conditions for $\mathrm{C}$ and $\mathrm{N}$ assimilation.

\section{MATERIALS AND METHODS}

\subsection{Plant material and experimental conditions}

Eight-month-old cork oak (Quercus suber L.) saplings were transplanted in July 1996 into $7.7 \mathrm{dm}^{3}$ pots filled exclusively with washed sand. Cotyledons were removed to induce early autotrophy. The experiment took place outdoors at the Instituto Superior de Agronomia (Lisbon, Portugal). Plants were regularly watered and, twice a week, fertilised with a complete nutrient solution $\left(6 \mathrm{~mol} \mathrm{~m}^{-3} \mathrm{~N}\right.$ in the form $\mathrm{NH}_{4} \mathrm{NO}_{3}$ ) as detailed in [17]. Spring growth flush began in March and lasted until July 1997. Between June and July new leaf emission was monitored.

\section{2. ${ }^{13} \mathrm{C}$ and ${ }^{15} \mathrm{~N}$ labeling}

Between December 1996 and January 1997, 45 plants were labeled with ${ }^{13} \mathrm{CO}_{2}$ and ${ }^{15} \mathrm{NH}_{4}{ }^{15} \mathrm{NO}_{3}$, respectively. Labeling was performed when no growth was expected. Three sets of 15 plants each were placed for five days in a growth cabinet (FITOCLIMA 700 EDTU, ARALAB, Portugal) where atmospheric $\mathrm{CO}_{2}$ was provided by a commercial cylinder with a ${ }^{13} \mathrm{CO}_{2} / 12 \mathrm{CO}_{2}$ ratio of 3.24 atom\% (CK Gas Products, ltd. UK). This ${ }^{13} \mathrm{CO}_{2}$ labeling cycle (5 days) was repeated for each set of plants. At the same time, all 45 labeled plants were fed, every two days, with a nutrient solution enriched in ${ }^{15} \mathrm{~N}(6$ atom\%) in the form ${ }^{15} \mathrm{NH}_{4}{ }^{15} \mathrm{NO}_{3}(\mathrm{CK}$ Gas Products, ltd. UK). Plants were placed in the cabinet the evening before the beginning of the labeling cycle. Just before to that, plant pots were enclosed individually in a plastic bag, tied at the collar by a rubber to improve adherence and to limit the emission of $\mathrm{CO}_{2}$ from root respiration. Temperature (min: $15^{\circ} \mathrm{C}$, max: $\left.25{ }^{\circ} \mathrm{C}\right)$, relative humidity $(55 \%)$, and $\mathrm{CO}_{2}$ concentration $(350 \mathrm{ppm})$ were controlled in the growth cabinet. Light (provided by incandescent and fluorescent lamps) switched on at 9:30 am and off at 5:30 pm. Its maximum intensity $\left(1000-1300 \mu \mathrm{mol} \mathrm{m}^{-2} \mathrm{~s}^{-1}\right)$ was reached half an hour later. Every day, in order to prevent discrimination against ${ }^{13} \mathrm{C}$ during $\mathrm{C}$ assimilation [3], $\mathrm{CO}_{2}$ supply was stopped two hours before the end of the photoperiod $(8 \mathrm{~h})$ and $\mathrm{CO}_{2}$ concentration was let to decrease down to the compensation point (about $100 \mathrm{ppm}$ ), as was assessed by a preliminary test. A ventilator in the lower part of the growth cabinet ensured a uniform $\mathrm{CO}_{2}$ concentration. The isotopic composition of atmospheric $\mathrm{CO}_{2}$ was indirectly assessed in the chamber and in the glasshouse by isotopic analysis of leaves of one-month-old Zea mays seedlings [24]. Maize leaves were harvested on day 3 and day 5 of each cycle in the growth cabinet.

Along the three labeling cycles, labeled and unlabeled plants stayed temporarily in a greenhouse. In this way differences between growth conditions of the 15 labeled plants in the cabinet for five days and of the remaining 30 labeled and 45 unlabeled plants were limited. Temperature and relative humidity in the greenhouse were controlled and similar to those in the growth-cabinet, while light irradiance was natural. Lateral windows allowed a continuous renewal of the air in the greenhouse. At the end of labeling, plants were transferred outside. 


\subsection{Plant harvest and isotopic analyses}

Destructive harvests were performed in January 1997 at the end of labeling, in March at the beginning of the new growth flush, and in August when new leaves were mature. For each harvest, 12 plants, six labeled and six at natural abundance of ${ }^{13} \mathrm{C}$ and ${ }^{15} \mathrm{~N}$, were collected. Biomass was divided into first year leaves (developed in 1996, before labeling), second year leaves (developed from March to July 1997) stem, branches, and coarse and fine roots. Plant material was dried in an oven $\left(70^{\circ} \mathrm{C}\right)$ for $48 \mathrm{~h}$, weighed and finely ground in a laboratory mill (MM2000, Retsch, Germany). Isotopic analyses were performed partly in an elemental analyser (NA 1500 NCS, Carlo Erba, Milan, Italy) coupled with a mass spectrometer (VGA optima, Fisons Micromass, England) at the "Institut de Biotechnologie des Plantes", Université de Paris Sud (Orsay, France), and partly in an elemental analyser (EA, Carlo Erba, Milan, Italy) coupled with a mass spectrometer (VG Sira, Serie II, England) at the "Istituto de Biologia Agroambientale e Forestale", Consiglio Nazionale delle Ricerche (Porano, Italia). The two machines were inter-calibrated.

Calculations were similar for ${ }^{13} \mathrm{C}$ and ${ }^{15} \mathrm{~N}$ [3, 31]. Only formulas for carbon $(\mathrm{C})$ are shown below, for nitrogen $(\mathrm{N})$ the suffix ${ }_{C}$ should be substituted with ${ }_{N}$. Parameters used are:

The relative specific allocation $\left(\mathrm{RSA}_{C}\right)$, expressed in percentage, which corresponds to the fraction of the all $\mathrm{C}$ (labeled and not labeled) incorporated during the labeling period, and allows estimating in each plant compartment the turnover rate of this element after the labeling period.

$$
\operatorname{RSA}_{C}=\frac{A_{\text {labeled sample }} \%-A_{\text {unlabeled sample }} \%}{A_{\text {labeled source }} \%-A_{\text {unlabeled source }} \%}
$$

where $A$ represents the isotopic abundance and was calculated as described in Deléens et al. [3]. $A_{\text {labeled sample }} \%$ is the isotopic abundance in a specific compartment of a labeled plant and $A_{\text {unlabeled sample }} \%$ is the average isotopic abundance of the respective compartment of the unlabeled plants. ${ }^{13} \mathrm{C}$ atom\% enrichment of Zea mays leaves, subjected to the same labeling cycle than cork oak saplings, was used to calculate $A_{\text {labeled source }} \%(1.36 \%, 1.53 \%$ and $1.41 \%$ for the three labeling cycles). $A_{\text {unlabeled source } \%}(1.097 \%)$ was obtained from Zea mays leaves not subjected to the enriched atmosphere in the growth cabinet. $A_{\text {labeled source }} \%$ and $A_{\text {unlabeled source }} \%$ for nitrogen were obtained from ${ }^{15} \mathrm{~N}$ atom\% in the labeled (6 atom\%) and unlabeled (0.39 atom\%) nutrient solution.

The winter $\mathrm{C}$ content was calculated for each plant part considering its dry mass and $\mathrm{C}$ concentration: Winter $\mathrm{C}\left(\mathrm{mg}\right.$ tree $\left.{ }^{-1}\right)=\mathrm{RSA}_{C} \times$ dry mass $\times \mathrm{C}$ concentration.

Partitioning of labeled $\mathrm{C}$ in plant was determined for each part as:

$$
P_{\text {winter } \mathrm{C}} \%=\frac{\text { winter } \mathrm{C}_{\text {part }}}{\text { winter } \mathrm{C}_{\text {plant }}} \times 100
$$

where the plant winter $\mathrm{C}$ content is given by the sum of the content of every individual part. Partitioning of winter $\mathrm{N}$ and total $\mathrm{C}$ and $\mathrm{N}$ were calculated with a similar procedure.

\subsection{Non-structural carbohydrate analyses}

Samples of leaves, stem, lateral branches and coarse roots were collected for non-structural carbohydrate determinations in six plants at each harvest. Leaf samples were always collected early in the morning $(8: 00 \mathrm{~h})$. First order branches were collected near their insertion point on the stem. Stem samples were collected below the insertion of the lower branch and coarse root samples few centimetres below the collar. The proportion of wood and bark tissues in samples was maintained equal to the original. Fresh material was immediately frozen in liquid nitrogen and stored at $-80^{\circ} \mathrm{C}$ until analyses. Soluble sugars were extracted in ethanol $(70 \%, \mathrm{v} / \mathrm{v})$, the residue was incubated in $\mathrm{HCl}$ $(1.1 \%, \mathrm{v} / \mathrm{v})$ for $30 \mathrm{~min}$ at $95^{\circ} \mathrm{C}$ for starch extraction. Both soluble sugars and starch were determined colorimetrically at $625 \mathrm{~nm}$ with anthrone reagent [28]. Results are expressed as the percentage of $\mathrm{C}$ in the carbohydrate per total C.

\subsection{Statistical analyses}

For every variable a one-way ANOVA was employed to analyse differences among harvest independently in each plant part as in the whole plant and in the biomass ratios. In order to compare $\mathrm{C}$ and $\mathrm{N}$ concentration as well as of the ratio $\mathrm{C}: \mathrm{N}$ between first year and second year leaves a t-test was performed for each harvest. Statistical analyses were performed following the procedure GLM of SPSS (SPSS Inc. Chicago, Illinois, USA, version 10.0.5). Transformations of the variables were performed when the necessary condition of homogeneity of variance was not verified. Tables and figures show always the original values. Morphological measurements done before the beginning of the experiment, height and leaf number were tested as covariates, in order to avoid misleading due to genetic differences between saplings. Their influence on the factor was always found not significant in biomass as in labelled $\mathrm{C}$ and $\mathrm{N}$ distributions. Consequently they were excluded by the analysis.

\section{RESULTS}

\subsection{Biomass accumulation and seasonal changes in total-non-structural carbohydrates concentration}

Total plant biomass increased about 6 times from March to August 1997 in labeled saplings (Tab. I). About 45\% of the plant biomass corresponded to coarse roots. Leaves $(20 \%)$, coarse roots $(45 \%)$ and stem $(17 \%)$ : plant ratios remained unchanged with time indicating a proportional biomass increase of these organs along the experiment. The same was not true for fine roots, which proportion to total plant biomass decreased from 18 to $8 \%$ between January and August and consequently also total root: plant ratio decreased significantly from March to August. The importance of wood in plant biomass increased with time reaching 30\% in August as a consequence of branch growth.

Coarse roots had the highest concentration in total nonstructural carbohydrates (TNC) (about $20 \%$ of total C) (Tab. II) followed by stem (16\%), leaves (13\%) and branches $(11 \%)$. Starch and TNC concentrations and starch/TNC ratio were never significantly different in the analysed plant parts (leaves, branches, stem and coarse roots). Only first year leaves showed in March a temporary decrease in starch concentration. This decrease affected the starch/TNC ratio but not TNC concentration.

\subsection{Seasonal changes in $\mathrm{C}$ and $\mathrm{N}$ concentration and $\mathrm{C}: \mathrm{N}$ ratio}

In March $\mathrm{C}$ concentration and the $\mathrm{C}: \mathrm{N}$ ratio (Tab. III) were higher in first year than in second year leaves. (t-test, respectively $P<0.01$ and $P<0.05$ ). In first year leaves $C$ concentration was constant along the experiment whereas in second year leaves it increased from March to August. As a consequence, at the end of the experiment, no more differences were appreciated between leaves of different age. 
Table I. Biomass of different plant parts of cork oak saplings, of the whole plant and the ratios of parts to the whole plant (\%). Values are the average of 6 replicates \pm one standard error. Different letters in the same line indicate significant differences to a One-way ANOVA $(P<0.05)$ within the same plant part or ratio.

\begin{tabular}{lccc}
\hline Part & January & March & August \\
\hline 1st year leaves & $0.98 \pm 0.20 \mathrm{a}$ & $1.28 \pm 0.19 \mathrm{a}$ & $0.75 \pm 0.15 \mathrm{a}$ \\
2nd year leaves & & $0.56 \pm 0.16 \mathrm{a}$ & $7.64 \pm 1.76 \mathrm{~b}$ \\
Branches (g) & & $6.38 \pm 1.65$ \\
Stem (g) & $0.67 \pm 0.13 \mathrm{a}$ & $1.22 \pm 0.21 \mathrm{a}$ & $8.49 \pm 1.11 \mathrm{~b}$ \\
Coarse root (g) & $1.83 \pm 0.29 \mathrm{a}$ & $3.97 \pm 0.75 \mathrm{a}$ & $22.00 \pm 1.69 \mathrm{~b}$ \\
Fine root (g) & $0.78 \pm 0.18 \mathrm{a}$ & $1.73 \pm 0.22 \mathrm{~b}$ & $4.02 \pm 0.55 \mathrm{c}$ \\
Plant (g) & $4.26 \pm 0.71 \mathrm{a}$ & $8.77 \pm 1.23 \mathrm{a}$ & $49.28 \pm 5.76 \mathrm{~b}$ \\
Stem:plant ratio (\%) & & $14.05 \pm 1.33 \mathrm{a}$ & $17.45 \pm 2.05 \mathrm{a}$ \\
Coarse root:plant ratio (\%) & $16.55 \pm 2.00 \mathrm{a}$ & $44.19 \pm 2.44 \mathrm{a}$ & $8.08 \pm 0.36 \mathrm{~b}$ \\
Fine root:plant ratio (\%) & $44.58 \pm 1.73 \mathrm{a}$ & $20.04 \pm 0.92 \mathrm{a}$ & $16.33 \pm 1.90 \mathrm{a}$ \\
Leaves:plant ratio (\%) & $17.61 \pm 2.30 \mathrm{a}$ & $21.71 \pm 1.46 \mathrm{a}$ & $29.63 \pm 3.03 \mathrm{~b}$ \\
Wood:plant ratio (\%) & $21.26 \pm 1.18 \mathrm{a}$ & $14.05 \pm 1.33 \mathrm{a}$ & $54.04 \pm 3.10 \mathrm{~b}$ \\
Root:plant ratio (\%) & $16.55 \pm 2.00 \mathrm{a}$ & $64.24 \pm 1.93 \mathrm{a}$ & \\
\hline
\end{tabular}

Table II. Starch, Total-non-structural carbohydrates (TNC) concentration, expressed as the percentage of C in the carbohydrate per total C, and the ratio starch/TNC (\%) in 1st and 2nd year leaves, branches, stem and coarse roots in two-year-old cork oaks. Each value is the average of six replicates \pm one standard error. Different letters in the same line means significant differences to a one-way ANOVA among harvests $(P<0.05)$

\begin{tabular}{|c|c|c|c|c|}
\hline Part & & January & March & August \\
\hline \multirow[t]{3}{*}{ 1st year leaves } & Starch & $5.11 \pm 0.33 \mathrm{a}$ & $3.54 \pm 0.23 b$ & $4.78 \pm 0.56 \mathrm{ab}$ \\
\hline & TNC & $14.47 \pm 0.83 \mathrm{a}$ & $12.95 \pm 1.27 \mathrm{a}$ & $13.08 \pm 0.43 \mathrm{a}$ \\
\hline & $\mathrm{Starch} / \mathrm{TNC}$ & $35.32 \pm 1.32 \mathrm{a}$ & $28.38 \pm 2.28 b$ & $36.43 \pm 2.42 \mathrm{a}$ \\
\hline \multirow[t]{3}{*}{ 2nd year leaves } & Starch & & $4.89 \pm 0.47 \mathrm{a}$ & $4.65 \pm 0.37 \mathrm{a}$ \\
\hline & $\mathrm{TNC}$ & & $15.03 \pm 1.71 \mathrm{a}$ & $13.16 \pm 1.37 \mathrm{a}$ \\
\hline & Starch/TNC & & $32.75 \pm 0.90 \mathrm{a}$ & $35.64 \pm 2.50 \mathrm{a}$ \\
\hline \multirow[t]{3}{*}{ Branches } & Starch & & & $7.10 \pm 0.70$ \\
\hline & $\mathrm{TNC}$ & & & $11.37 \pm 0.68$ \\
\hline & Starch/TNC & & & $61.97 \pm 2.86$ \\
\hline \multirow[t]{3}{*}{ Stem } & Starch & $9.96 \pm 1.69 \mathrm{a}$ & $10.11 \pm 0.85 \mathrm{a}$ & $11.47 \pm 1.00 \mathrm{a}$ \\
\hline & $\mathrm{TNC}$ & $14.80 \pm 1.88 \mathrm{a}$ & $14.80 \pm 1.15 \mathrm{a}$ & $15.96 \pm 1.05 \mathrm{a}$ \\
\hline & $\mathrm{Starch} / \mathrm{TNC}$ & $66.64 \pm 4.99 \mathrm{a}$ & $68.16 \pm 1.66 \mathrm{a}$ & $71.71 \pm 3.89 \mathrm{a}$ \\
\hline \multirow[t]{3}{*}{ Coarse root } & Starch & $19.75 \pm 0.66 \mathrm{a}$ & $19.26 \pm 1.95 \mathrm{a}$ & $20.83 \pm 3.09 \mathrm{a}$ \\
\hline & $\mathrm{TNC}$ & $24.16 \pm 0.67 \mathrm{a}$ & $22.59 \pm 2.27 \mathrm{a}$ & $25.78 \pm 3.52 \mathrm{a}$ \\
\hline & Starch/TNC & $81.90 \pm 2.75 \mathrm{a}$ & $85.26 \pm 1.45 \mathrm{a}$ & $80.04 \pm 1.39 \mathrm{a}$ \\
\hline
\end{tabular}

$\mathrm{N}$ concentration decreased in both first year and second year leaves from March to August. The decrease was greater in the first year than in second year leaves. As a consequence, in August, second year leaves had higher $\mathrm{N}$ concentration than first year leaves $(t$-test, $P<0.05)$. The simultaneous increase in $\mathrm{C}$ and decrease in $\mathrm{N}$ concentration from March to August in second year leaves led to an increase of the $\mathrm{C}: \mathrm{N}$ ratio in this period. In first year leaves, similar changes in the $C: N$ ratios during the same period were only the consequence of the lower $\mathrm{N}$ concentration observed in August.

In stem, coarse and fine roots $\mathrm{N}$ concentration decreased from March to August. The C:N ratio was significantly higher at the end of the experiment in stem and coarse roots, while in fine roots a marked variability did not allow to distinguish significant differences among harvests. The decrease observed in $\mathrm{N}$ concentration in all plant parts at the August harvest led to a decrease of $\mathrm{N}$ concentration in the whole plant and to a consequent increase of the $\mathrm{C}: \mathrm{N}$ ratio.

\subsection{Seasonal changes of the relative specific allocation of $\mathrm{C}$ and $\mathrm{N}$ assimilated the previous winter}

From January to August, both $\mathrm{RSA}_{C}$ and $\mathrm{RSA}_{N}$ decreased (Tab. IV) as a consequence of continuous assimilation of new 
Table III. Carbon (C) and Nitrogen concentration (N) and the ratio of the two $(\mathrm{C}: \mathrm{N})$ in different plant parts and in the whole plant. Values are the average of 6 replicates \pm one standard error. Different letters in the same line means significant differences to a One-way ANOVA among harvests $(P<0.05)$. Differences between leaves of different age were tested at each harvest by a t-test (see Results). Plant values are weighted averages of all analysed parts.

\begin{tabular}{|c|c|c|c|c|c|c|c|c|c|}
\hline \multirow{2}{*}{ Part } & \multicolumn{3}{|c|}{ Carbon (\%) } & \multicolumn{3}{|c|}{ Nitrogen (\%) } & \multicolumn{3}{|c|}{$\mathrm{C}: \mathrm{N}$} \\
\hline & January & March & August & January & March & August & January & March & August \\
\hline 1st year leaves & $50.03 \pm 0.54 \mathrm{a}$ & $49.89 \pm 1.06 \mathrm{a}$ & $48.54 \pm 0.29 \mathrm{a}$ & $2.35 \pm 0.14 \mathrm{a}$ & $2.42 \pm 0.09 \mathrm{a}$ & $1.48 \pm 0.12 \mathrm{~b}$ & $21.66 \pm 1.30 \mathrm{a}$ & $20.73 \pm 0.85 \mathrm{a}$ & $34.03 \pm 3.08 b$ \\
\hline 2nd year leaves & & $43.43 \pm 0.89 a$ & $48.72 \pm 0.34 \mathrm{~b}$ & & $2.40 \pm 0.06 \mathrm{a}$ & $1.82 \pm 0.09 \mathrm{~b}$ & & $18.14 \pm 0.68 \mathrm{a}$ & $27.18 \pm 1.56 \mathrm{~b}$ \\
\hline Branches & & & $45.91 \pm 0.22$ & & & $1.06 \pm 0.08$ & & & $44.37 \pm 3.21$ \\
\hline Stem & $47.91 \pm 0.69 \mathrm{a}$ & $45.87 \pm 1.28 \mathrm{a}$ & $45.56 \pm 0.39 a$ & $1.45 \pm 0.07 \mathrm{ab}$ & $1.99 \pm 0.20 \mathrm{a}$ & $1.02 \pm 0.13 b$ & $39.77 \pm 7.01 \mathrm{ab}$ & $24.12 \pm 2.21 \mathrm{a}$ & $47.86 \pm 5.05 b$ \\
\hline Coarse Roots & $46.87 \pm 0.49 \mathrm{ab}$ & $48.83 \pm 0.99 \mathrm{a}$ & $46.06 \pm 0.37 \mathrm{~b}$ & $1.73 \pm 0.17 \mathrm{a}$ & $1.99 \pm 0.21 \mathrm{a}$ & $1.07 \pm 0.11 \mathrm{~b}$ & $28.54 \pm 2.85 \mathrm{a}$ & $25.94 \pm 2.87 \mathrm{a}$ & $45.25 \pm 4.87 \mathrm{~b}$ \\
\hline Fine roots & $47.20 \pm 1.30 \mathrm{ab}$ & $50.66 \pm 0.98 \mathrm{a}$ & $46.22 \pm 1.14 \mathrm{~b}$ & $1.91 \pm 0.17 \mathrm{a}$ & $1.99 \pm 0.13 \mathrm{a}$ & $1.21 \pm 0.13 \mathrm{~b}$ & $25.54 \pm 2.04 \mathrm{a}$ & $26.04 \pm 1.96 \mathrm{a}$ & $42.37 \pm 9.49 \mathrm{a}$ \\
\hline Plant average & $47.79 \pm 0.66 \mathrm{ab}$ & $48.61 \pm 0.33 \mathrm{a}$ & $46.47 \pm 0.25 b$ & $1.84 \pm 0.10 \mathrm{a}$ & $2.08 \pm 0.13 \mathrm{a}$ & $1.19 \pm 0.09 b$ & $26.68 \pm 1.32 \mathrm{a}$ & $23.78 \pm 1.46 \mathrm{a}$ & $40.09 \pm 3.10 b$ \\
\hline
\end{tabular}

Table IV. Carbon $\left(\mathrm{RSA}_{C}\right)$ and nitrogen $\left(\mathrm{RSA}_{N}\right)$ relative specific allocation and the ratio of the two $\left(\mathrm{RSA}_{C} / \mathrm{RSA}_{N}\right)$ measured in different plant parts and in the whole plant. Each value is the average of six replicates \pm one standard error. Different letters in the same line indicate significant differences to a one-way ANOVA $(P<0.05)$.

\begin{tabular}{|c|c|c|c|}
\hline \multicolumn{4}{|c|}{$\operatorname{RSA}_{C}(\%)$} \\
\hline Part & January & March & August \\
\hline 1st year leaves & $22.18 \pm 3.90 \mathrm{a}$ & $11.55 \pm 2.98 \mathrm{ab}$ & $7.80 \pm 2.00 \mathrm{~b}$ \\
\hline 2nd year leaves & & $9.04 \pm 2.74 \quad \mathrm{a}$ & $1.90 \pm 1.13 \mathrm{~b}$ \\
\hline Branches & & & $0.23 \pm 0.05$ \\
\hline Stem & $15.82 \pm 1.83 \mathrm{a}$ & $11.11 \pm 0.97 \mathrm{a}$ & $1.26 \pm 0.35 b$ \\
\hline Coarse root & $10.25 \pm 2.24 \mathrm{a}$ & $6.27 \pm 0.90 \quad \mathrm{a}$ & $1.04 \pm 0.24 \mathrm{~b}$ \\
\hline Fine root & $13.34 \pm 1.96 \mathrm{a}$ & $8.91 \pm 2.11 \mathrm{a}$ & $1.10 \pm 0.34 \mathrm{~b}$ \\
\hline Plant & $14.22 \pm 1.71 \mathrm{a}$ & $8.76 \pm 0.80 \quad a$ & $1.20 \pm 0.31 \mathrm{~b}$ \\
\hline \multicolumn{4}{|c|}{$\mathrm{RSA}_{N}(\%)$} \\
\hline Part & January & March & August \\
\hline 1st year leaves & $53.61 \pm 3.56 \mathrm{a}$ & $29.09 \pm 1.41 b$ & $17.48 \pm 3.39 \mathrm{c}$ \\
\hline 2nd year leaves & & $51.21 \pm 3.35 \mathrm{a}$ & $8.65 \pm 1.69 b$ \\
\hline Branches & & & $4.71 \pm 0.29$ \\
\hline Stem & $70.08 \pm 1.25 \mathrm{a}$ & $32.35 \pm 1.36 \mathrm{~b}$ & $9.72 \pm 1.16 \mathrm{c}$ \\
\hline Coarse root & $70.99 \pm 1.29 \mathrm{a}$ & $36.85 \pm 2.08 b$ & $11.15 \pm 0.65 \mathrm{c}$ \\
\hline Fine root & $67.80 \pm 3.35 \mathrm{a}$ & $26.11 \pm 1.45 b$ & $5.96 \pm 1.02 \mathrm{c}$ \\
\hline Plant & $66.47 \pm 1.96 \mathrm{a}$ & $33.87 \pm 1.11 \mathrm{~b}$ & $9.31 \pm 0.69 \mathrm{c}$ \\
\hline \multicolumn{4}{|c|}{$\mathrm{RSA}_{C} / \mathrm{RSA}_{N}$} \\
\hline Part & January & March & August \\
\hline 1st year leaves & $0.41 \pm 0.06 \quad \mathrm{a}$ & $0.38 \pm 0.09 a$ & $0.42 \pm 0.08 \mathrm{a}$ \\
\hline 2nd year leaves & & $0.19 \pm 0.06 \mathrm{a}$ & $0.18 \pm 0.08 \mathrm{a}$ \\
\hline Branches & & & $0.05 \pm 0.01$ \\
\hline Stem & $0.23 \pm 0.03 \mathrm{ab}$ & $0.34 \pm 0.03 \mathrm{a}$ & $0.12 \pm 0.03 \mathrm{~b}$ \\
\hline Coarse root & $0.14 \pm 0.03 \quad \mathrm{a}$ & $0.17 \pm 0.02 \mathrm{a}$ & $0.09 \pm 0.02 \mathrm{a}$ \\
\hline Fine root & $0.19 \pm 0.02 a$ & $0.34 \pm 0.08 \mathrm{a}$ & $0.19 \pm 0.05 \mathrm{a}$ \\
\hline Plant & $0.21 \pm 0.02 \mathrm{ab}$ & $0.26 \pm 0.02 \mathrm{a}$ & $0.13 \pm 0.03 b$ \\
\hline
\end{tabular}

$\mathrm{C}$ and $\mathrm{N}$, since RSA depends on the turnover rate of an element in the plant.

In first year and second year leaves, both $\mathrm{RSA}_{C}$ and $\mathrm{RSA}_{N}$ decrease from January to August in a parallel way and the ratio of the two was always constant. The same was true for coarse and fine roots, despite the decrease observed in $\mathrm{RSA}_{C}$ was significant only between March and August. In stem and in the whole plant, from March to August, the decrease in $\mathrm{RSA}_{C}$ was steeper than that in $\mathrm{RSA}_{N}$ resulting in a significant decrease in the ratio of the two.

\subsection{Seasonal changes in content and partitioning of winter $\mathrm{C}$ and $\mathrm{N}$ in plants}

Winter $\mathrm{C}$ and $\mathrm{N}$ represent the amount of $\mathrm{C}$ and $\mathrm{N}$ assimilated during labeling time, part of which accumulated as storage. The amount of winter $\mathrm{C}$ decreased gradually in first year leaves from January to August (Fig. 1), whereas total C content did not change significantly. From March to August, a decrease in the amount of winter $\mathrm{C}$ was also observed in fine roots. In other plant parts (second year leaves, stem and coarse roots), winter C was constant throughout the harvests. In branches the amount of winter $\mathrm{C}$ was very small: about 50 times lower than in the whole plant. Despite the decrease observed in August in first year leaves and fine roots, the winter $\mathrm{C}$ of the whole plant was not significantly different among harvests.

Both winter and total $\mathrm{N}$ decreased strongly from March to August in first year leaves (Fig. 2). In second year leaves, stem, coarse roots, and in the whole plant, winter $\mathrm{N}$ was constant among the harvests, whereas total $\mathrm{N}$ increased continuously. In fine roots, winter $\mathrm{N}$ decreased markedly from March to August whereas total $\mathrm{N}$ remained constant.

The pattern of carbon partitioning among organs was different in August (when the seasonal shoot growth flush was completed) as compared to previous harvests (Fig. 3A): partitioning of $\mathrm{C}$ to wood (stem + branches) was increased, whereas root $\mathrm{C}$ partitioning decreased. Also N partitioning increased in August in wood as compared to previous harvests (Fig. 3B). Both winter $\mathrm{C}$ and winter $\mathrm{N}$ partitioning did not change throughout the harvests (Figs. 3C and 3D). 

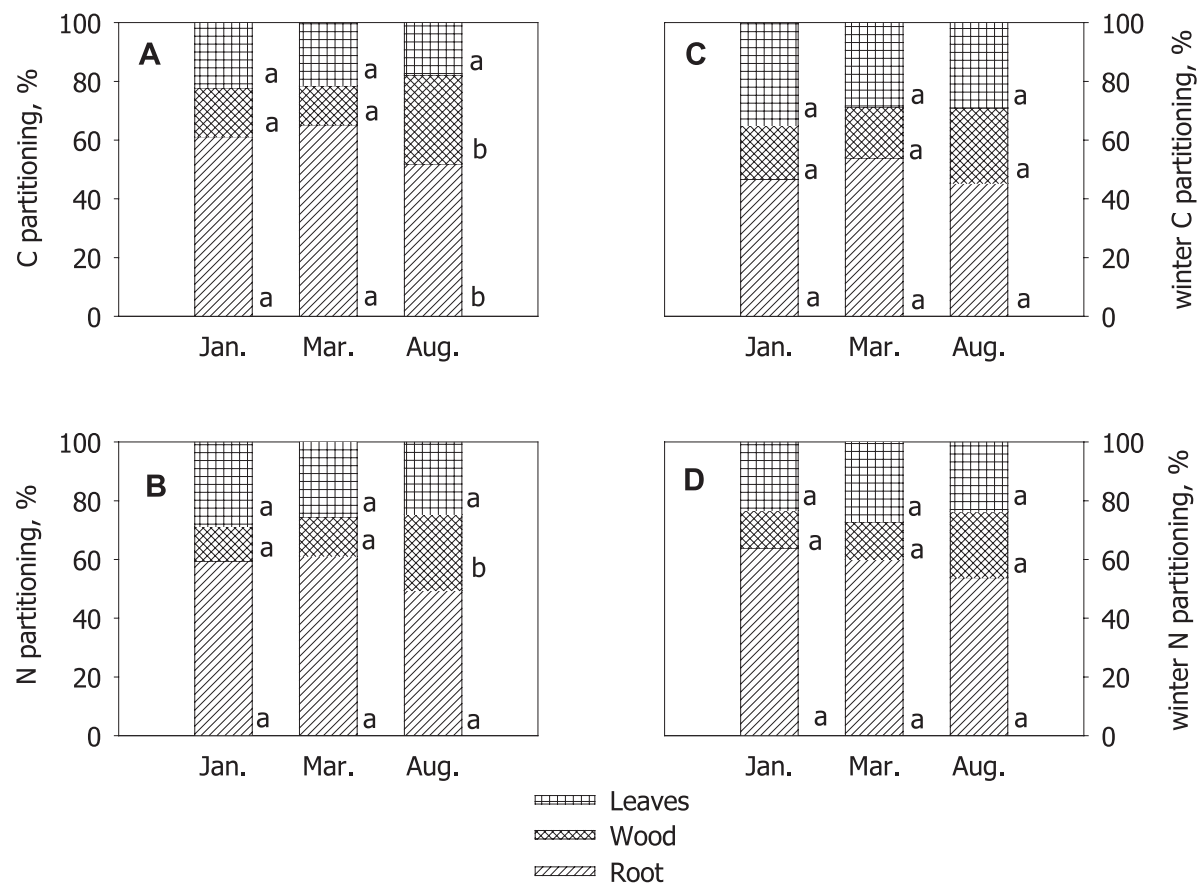

Figure 3. Total C (A), total $\mathrm{N}(\mathbf{B})$, winter $\mathrm{C}(\mathbf{C})$ and winter $\mathrm{N}(\mathbf{N})$ partitioning among leaves, wood and root. Each Value is the average of six replicates. Different letters for the same part indicate significant differences to a One-Way ANOVA among harvests.

\section{DISCUSSION}

\subsection{Winter $\mathrm{C}$ and $\mathrm{N}$ internal mobilization}

Contents of winter $\mathrm{C}$ and $\mathrm{N}$ of two-year-old cork oak plants did not decrease significantly from harvest to harvest, indicating that saplings kept $\mathrm{C}$ and $\mathrm{N}$ assimilated during the previous winter. This result suggests also that respiration does not use stored $\mathrm{C}$ but rather more recent assimilates and that winter $\mathrm{C}$ and $\mathrm{N}$ losses due to senescence or roots exudation did not occur or was negligible in comparison to the whole plant pool.

Winter $\mathrm{C}$ and $\mathrm{N}$ were found in organs developed after labeling: second year leaves, fine roots and branches, demonstrating that internal mobilization of winter stored $\mathrm{C}$ and $\mathrm{N}$ occurred. However the allocation of winter $\mathrm{C}$ and $\mathrm{N}$ to branches was much lower than to any other plant part. Time differences observed in growth of leaves and branches led to differences in the use of both reserves and new assimilates by these organs. Particularly, our results showed that spring leaves used more reserves for their growth than branches formed later in the season. No important mobilization was observed from stem or coarse roots, confirming that cork oak behave mainly as an evergreen plant $[5,19]$ mobilizing storage more from leaves than from perennial organs, in spite of the relatively short leaf duration (ca. one year) as compared to other evergreens [23].

\subsection{Sources and sinks for winter $C$ and $N$}

First year leaves showed a decrease in the amount of winter $\mathrm{N}$ in August just before senescence. A withdrawal of leaf reserves before their fall was already demonstrated for $\mathrm{N}$ in the Mediterranean evergreen Quercus ilex L. [26]. Our results showed also a decrease of winter $\mathrm{C}$ from January to August in first year leaves. Since both starch and the starch/TNC concentrations did not decrease from March to August in first year leaves, the results suggest that the eventual loss of winter $C$ in the form of carbohydrates was compensated by the accumulation of new carbohydrates in this period. At the same time the remobilisation of winter $\mathrm{N}$ from first year leaves suggests that hydrolysis of storage proteins and export of amino acids may have occurred [29].

An export of winter $\mathrm{C}$ and $\mathrm{N}$ was also observed from fine roots. The explanation for such a result should consider that the ratio fine root: plant biomass decreased from March to August suggesting that fine roots were subjected to a fast turnover [14]. So, similarly to what happens in first year leaves, cork-oak fine roots export $\mathrm{C}$ and $\mathrm{N}$ before dying, as was already observed in the evergreen Sitka spruce (Picea sitchensis (Bong.) Carr.) [7].

Despite the changes observed throughout the year in winter $\mathrm{C}$ and $\mathrm{N}$, their partitioning among the main classes of organs (leaves, wood and roots) was never markedly different along the experiment. Such a result suggests that, in cork oak saplings, the flow of $\mathrm{C}$ and $\mathrm{N}$ from source to sink organs operates preferentially within the shortest source-sink distance, from first year leaves to new leaves, from stem to branches and from old fine roots to growing roots. Evidences for $\mathrm{N}$ translocation from old to new leaves were already found in conifers [19] as well as in broadleaf evergreens such as Eucalyptus globulus Labill. [32]. 


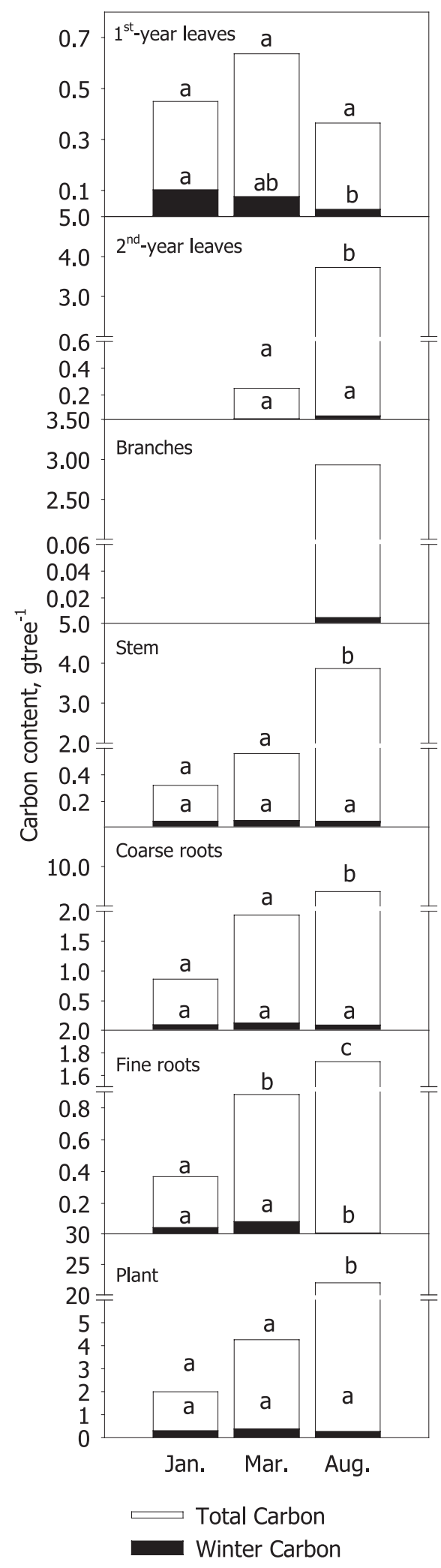

Figure 1. Total (open bars) and winter (closed bars) carbon in first and second year leaves, branches, stem, coarse and fine roots and in the whole plant. Each value is the average of six replicates. Different letters indicate significant differences to a One-way ANOVA $(P<0.05)$ among harvests.

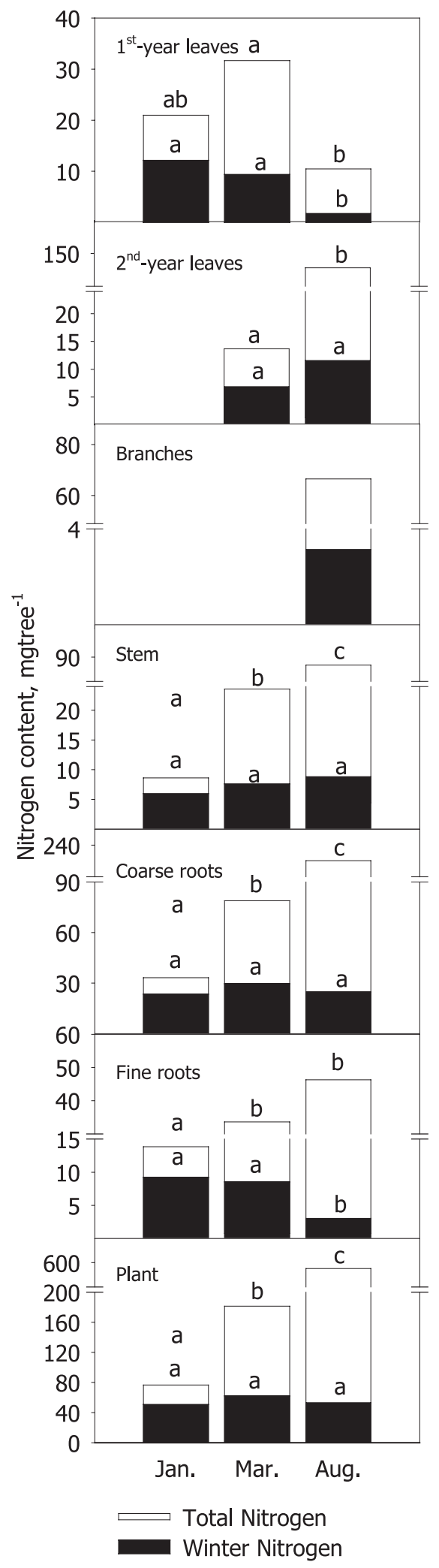

Figure 2. Total (open bars) and winter (closed bars) nitrogen in first and second year leaves, branches, stem, coarse and fine roots and in the whole plant. Each value is the average of six replicates. Different letters indicate significant differences to a One-way ANOVA $(P<0.05)$. 


\subsection{Recent assimilates mobilisation and changes in starch pool}

Our results show that new assimilates cooperated with reserves to sustain the seasonal flush growth of cork oak saplings. $\mathrm{N}$ partitioning in leaves did not show any change along the experiment, whereas a decrease was observed in total $\mathrm{N}$ content in old leaves in August. These results suggest that not only winter $\mathrm{N}$ but also recently assimilated $\mathrm{N}$ were withdrawn from old to spring leaves before their fall.

Only at the beginning of the growth flush, in March, the decrease in the ratio starch/TNC observed in first year leaves suggests a trend to export photoassimilates from old to new leaves, as sucrose is the preferred form for the transport of carbohydrates within the plant [15]. The last result suggests that remobilisation of $\mathrm{C}$ from old to new leaves is more dependent on the presence of strong sinks, like new developing leaves than on leaf senescence. In any other part plant (stem, branches and coarse root) our results show no significant changes in starch and TNC concentration among harvests. Anyway, the time gap between harvests was quite big and did not allow excluding that a temporary decrease in TNC amount or in the ratio starch/TNC occurred. Anyway, if this is the case, TNC availability was shortly re-established.

\subsection{Carbon/Nitrogen equilibrium}

The metabolisms of $\mathrm{C}$ and $\mathrm{N}$ in the plant are strictly interdependent [9]. As a consequence both $\mathrm{C}$ and $\mathrm{N}$ storage will be mobilized when necessary to support new growth. In our experiment we observed that $\mathrm{C}$ and $\mathrm{N}$ reallocation proceeded in a parallel way as the ratio $\mathrm{RSA}_{\mathrm{C}} / \mathrm{RSA}_{\mathrm{N}}$ was practically constant along the experiment. Similarly, the partitioning of winter $\mathrm{C}$ and $\mathrm{N}$ and the partitioning of the whole $\mathrm{C}$ and $\mathrm{N}$ in the plant proceeded in a very similar way. As a consequence our results suggest an equilibrate utilization of storage for both $\mathrm{C}$ and $\mathrm{N}$ at the whole plant level under non-limiting conditions for their assimilation. Obviously different experimental conditions could influence results. For example, in Sitka spruce (Picea sitchensis (Bong.) Carr.), it was demonstrated that trees grown at low $\mathrm{N}$ conditions remobilised a bigger proportion of $\mathrm{N}$ from roots than trees grown at high $\mathrm{N}$ conditions [18], affecting nitrogen partitioning.

Our results show the importance of pre-existing leaves for the spring growth flush of cork oak plants. In the Mediterranean type of climate an important pulse of nutrient availability may occur in autumn when litter accumulated throughout the summer decomposes with the first rains. Cork oak, as other evergreen trees, may use this pulse of nutrient availability for uptake and storage with existing foliage acting as reservoirs. Together with the possibility of assimilating $\mathrm{C}$ in winter (when water is available in the Mediterranean climate), this pattern of storage and use may be one of the advantages of this species in keeping older leaves until the new foliage is completely developed.

Acknowledgments: Authors are indebted to the last Eliane Deléens (IBP- Paris, France) for her help in the design of the labeling experiment. This project was funded by the Portuguese government through FCT (GGPXXI/BD/976 and SFRH/BPD/14603/2003).

\section{REFERENCES}

[1] Carvalho P.O., Ciclo interno do azoto em árvores, Ph.D. thesis, Departamento de Engenharia Florestal, Instituto Superior de Agronomia, Lisbon, 1997.

[2] Chapin I.F.S., Schulze E.D., Mooney H.A., The ecology and economics of storage in plants, Annu. Rev. Ecol. Syst. 21 (1990) 423-447.

[3] Deléens E., Cliquet J.B., Prioul J.L., Use of ${ }^{13} \mathrm{C}$ and ${ }^{15} \mathrm{~N}$ plant label near natural abundance for monitoring carbon and nitrogen partitioning, Aust. J. Plant Physiol. 21 (1994) 133-146.

[4] Dickson R.E., Carbon and nitrogen allocation in trees, Ann. Sci. For. 46 (1989) 631-647.

[5] Egger B., Einig W., Schlereth A., Wallenda T., Magel E., Loewe A., Hampp R., Carbohydrate metabolism in one- and two-year-old spruce needles, and stem carbohydrates from three months before until three months after bud break, Physiol. Plant. 96 (1996) 91100 .

[6] Escudero A., Del Arco J.M., Sanz I.C., Ayala J., Effects of leaf longevity and retranslocation efficiency on the retention time of nutrients in the leaf biomass of different woody species, Oecologia 90 (1992) 80-87.

[7] Ferrier R.C., Alexander I.J., Internal redistribution of $\mathrm{N}$ in Sitka spruce seedlings with partly droughted root systems, For. Sci. 62 (1991) 861-869.

[8] Fialho C., Lopes F., Pereira H., The effect of cork removal on the radial growth and phenology of young cork oak trees, For. Ecol. Manage. 141 (2001) 251-258.

[9] Foyer C.H., Ferrario S., Noctor G., Interactions between carbon and nitrogen metabolism, in: Lea P.J., Morot Gaudry J.F. (Eds.), Plant Nitrogen, Springer-Verlag, Berlin, 2001, pp. 237-254.

[10] Gholz H.L., Cropper W.P.J., Carbohydrate dynamics in mature Pinus elliottii var. elliottii trees, Can. J. For. Res. 21 (1991) 17421747.

[11] Lacointe A., Kajji A., Archer P., Frossard J.S., Mobilization of carbon reserves in young walnut trees, Acta Bot. Gallica 4 (1993) 435441.

[12] Lacointe A., Sauter J.J., Ameglio T., Harms U., Pellicer V., Frossard J.S., Carbohydrate and protein reserves in trees, in EUROSILVA Contribution to Forest Tree Physiology, INRA, Dourdan, 1994.

[13] Legaz F., Serna M.D., Primo-Millo E., Mobilization of the reserve $\mathrm{N}$ in citrus, Plant Soil 173 (1995) 205-210.

[14] López B., Sabaté S., Gracia C.A., Fine-root longevity of Quercus ilex, New Phytol. 151 (2001) 437-441.

[15] Magel E., Einig W., Hampp R., Carbohydrates in trees, in: Gupta A.K., Kaur N. (Eds.), Carbohydrate reserve in plants - synthesis and regulation, Elsevier Science, 2000, pp. 318-336.

[16] Maillard P., Guehl J.M., Muller J.F., Gross P., Interactive effects of elevated $\mathrm{CO}_{2}$ concentration and nitrogen supply on partitioning of newly fixed ${ }^{13} \mathrm{C}$ and ${ }^{15} \mathrm{~N}$ between shoot and roots of pedunculate oak seedlings (Quercus robur), Tree Physiol. 21 (2001) 163-172.

[17] Millard P., Proe M.F., Leaf demography and the seasonal internal cycling of nitrogen in sycamore (Acer pseudoplatanus L.) seedlings in relation to nitrogen supply, New Phytol. 117 (1991) 587-596.

[18] Millard P., Proe M.F., Storage and internal cycling of nitrogen in relation to seasonal growth of Sitka spruce, Tree Physiol. 10 (1992) 33-43.

[19] Nambiar E.K.S., Fife D.N., Growth and nutrient retranslocation in neeedles of radiata pine in relation to nitrogen supply, Ann. Bot. 60 (1987) 147-156.

[20] Oliveira G., Martins-Loucao M.A., Correia O., Catarino F. Nutrient dynamics in crown tissues of cork-oak (Quercus suber L.), Trees-Struct. Funct. 10 (1996) 247-254.

[21] Parry M., Assessments of potential effects and adaptations for climate change in Europe - The Europe Acacia project, European Commission: University of East Anglia, UK, 2000.

[22] Pellicer V., Guehl J.M., Daudet F.A., Cazet M., Riviere L.M., Maillard P., Carbon and nitrogen mobilization in Larix $\times$ eurolepis 
leafy stem cuttings assessed by dual ${ }^{13} \mathrm{C}$ and ${ }^{15} \mathrm{~N}$ labeling: relationships with rooting, Tree Physiol. 20 (2000) 807-814.

[23] Pereira J.S., Beyschlag G., Lange O.L., Beyschlag W., Tenhunen J.D., Comparative phenology of four Mediterranean shrub species growing in Portugal, in: Tenhunen J.D., Catarino F.M., Lange O.L. Oechel W.C. (Eds.), Plant response to stress, Springer-Verlag, Berlin, 1987, pp. 503-514.

[24] Picon C., Ferhi A., Guehl J.M., Concentration and $\delta^{13} \mathrm{C}$ of leaf carbohydrates in realtion to gas exchange in Quercus robur under elevated $\mathrm{CO}_{2}$ and drought, J. Exp. Bot. 48 (1997) 1547-1556.

[25] Piispanen R., Saranpää P., Variation of non-structural carbohydrates in silver birch (Betula pendula Roth) wood, Trees 15 (2001) 444-451.

[26] Rapp M., Santa Regina I., Rico M., Antonio-Gallego H., Biomass, nutrient content, litterfall and nutrient return to the soil in Mediterranean oak forests, For. Ecol. Manage. 119 (1999) 39-49.

[27] Robert B., Caritat A., Bertoni G., Vilar L., Molinas M., Nutrient content and seasonal fluctuations in the leaf components of corkoak (Quercus suber L.) litterfall, Vegetatio 122 (1996) 29-35.
[28] Robyt J.F., White B.J., Biochemical techniques. Theory and practice, Waveland Press, 1990.

[29] Sauter J.J., Van Cleve B., Seasonal variations of amino acids in the xylem sap of "Populus $\times$ canadensis" and its relation to protein body mobilisation, Trees (1992) 26-32.

[30] Tagliavini M., Millard P., Quartieri M., Storage of foliar-absorbed nitrogen and remobilization for spring growth in young nectarine (Prunus persica var. nectarina) trees, Tree Physiol. 18 (1998) 203 207.

[31] Vivin P., Martin F., Guehl J.M., Acquisition and within-plant allocation of ${ }^{13} \mathrm{C}$ and ${ }^{15} \mathrm{~N}$ in $\mathrm{CO}_{2}$ - enriched Quercus robur plants, Physiol. Plant. 98 (1996) 89-96.

[32] Wendler R., Carvalho P.O., Pereira J.S., Millard P., Role of nitrogen remobilization from old leaves for new leaf growth of Eucalyptus globulus seedlings, Tree Physiol. 15 (1995) 679-683.

[33] Witt W., Sauter J.J., Starch metabolism in poplar wood ray cells during spring mobilization and summer deposition, Physiol. Plant. (1994) 9-16. 